\title{
Erasure, discovery and emergence: The Buderim-Palmwoods Heritage Tramway walking track assemblage
}

\author{
Janis Hanley \\ janis.hanley@griffithuni.edu.au
}

\section{Abstract}

A serene little walking track graces the hillside along Mons Road between Buderim and the Bruce Highway. It marks a significant piece of state heritage: the Buderim-Palmwoods Tramway. Behind it lies a story of community driving discovery, emergence, conservation and use. This article tells of the emergence of the walking track using Deleuze and Guattari's assemblage concept to explore the 'becoming' of the walking track. Assemblages provide an understanding of heritage as a process rather than a fixed entity, examining the reterritorialisation of the tramway track and the ways in which its boundaries are constantly challenged by human and non-human elements. The continuums of territorialisation/deterritorialisation and materiality/expression offer insights into heritage management. Analysis of the tramway as a heritage assemblage reveals the ongoing process of caring for heritage: it shows the strengths of clear boundaries, and permeable ones, and the importance of both material and expressive roles of the components comprising a heritage place. An assemblage view moves conservation beyond the fabric, the architectural and aesthetic to the interplay of the atmospheric, the emotional and the expressive, recognising the action and agency of heritage components and their ability to affect and be affected.

\section{Introduction}

Ron Hooper is one of a handful of people old enough to remember seeing the Buderim-Palmwoods tramway in operation. He clearly recollects watching the tram from the town of Buderim chuffing through his uncle's orchard at Forest Glen, crossing the road (now the Bruce highway) on its way to Palmwoods station. The Hoopers were an old Sunshine Coast family, arriving in the area in 1884 and pioneering fruit farming in Forest Glen. Ron remembers local farmers from the Mons area bringing fruit to the Telko station and loading it onto the tram. His late wife, Marj, travelled on the tram as a baby. In 1946, after returning from service in World War II, Ron bought his own allotment of 16 acres (6.5 hectares) along Mons 
Road adjacent to Telko Road, bordering the route of the old tramway, which had been shut down in 1935. In his interview, Ron told of endless days grubbing the land (pulling up roots and stumps) by hand, and planting strawberries, pineapples and bananas. A clogged culvert of a bordering tramway embankment nicely formed a dam, giving Ron all the water he needed. Ron spoke of the nearby Telko Road bridge collapsing: 'a chappy [in a truck] ... just got across, and the back went down into it. The bridge collapsed.' Ron said the old tramway bridge crossing underneath, itself '50 foot (15 metres) high', was 'cut down' soon after, its timbers 'as good as the day it was built' (Ron Hooper interview 2017). Ron and Marj's children grew up with the abandoned tramway track as an extension of their backyard, riding bicycles and later even driving an old cut-down Dodge truck along the track. Family and neighbours worked to keep the track clear of lantana and debris. Gradually the children grew up and left, and the bush reclaimed another set of memories.

The history of the tramway is well documented by the Buderim-Palmwoods Heritage Tramway Incorporated (BPTHI) (Fraser and McGarvie 2010, 2014). In the 1890s, community discussions about a railway started, prompted by regular heavy rains that made mountain roads impassable for bullock drays and wagons carrying produce to markets, leaving crops rotting. Finally in 1913, after the Buderim community had commissioned an engineer to settle on the route, the Maroochydore Shire Council and the Queensland Government agreed to provide a loan for a 2 foot, 6 inch ( 75 centimetres) gauge tramway running between Palmwoods and Buderim. Technically a train, the engine was deemed to be a tram to qualify for a state government tramway grant. The final tramway cost was almost double initial estimates — $£ 40,000$ (in terms of labour costs today, $\$ 24,590,000) .{ }^{1}$ This loan was to be repaid through tramway revenue, but mostly by the local community through levying council rates; farmers donated the necessary land, so no resumptions were required.

Unforeseen when planning the tramway was the advent of motor transport. Investment in road systems in the 1920 s, combined with the economic depression, made the tramway unprofitable, and it ceased operation in 1935, after only twentytwo years in service. Its ignoble end was reported in the Nambour Chronicle under the headline 'Vale Buderim tram!'

To enter service as a miracle of transport, greeted with loud sirens, cheers, gay bunting and the congratulations ... and to terminate such service without even the blast from its own whistle ... What the inauguration of the tram served to Buderim cannot be fully grasped by the present generation ... the steady means of transport made the mountain boom. Fruit production increased enormously, land values rose to heights. ('Vale Buderim tram' 1935)

It is difficult not to anthropomorphise the last trip of the little Krauss engine down the mountain, pulling up its own tracks, laying bare the sleepers and loading the precious iron onto its carriages on its final journey, never to return to Buderim in working order. Over time, the bridge and station infrastructure were removed and repurposed. The community loan repayments went on, however, and were not repaid until 1971. According to reports in the Nambour Chronicle, the pre-1939 period was difficult and tumultuous for the residents. After twenty years of repayments, only ' $£ 5000$ of the $£ 34,000$ [\$3,074,000 of the $\$ 20,900,000]$ debt had been repaid and the community had paid $£ 20000[\$ 12,290,000]$ in interest' 
('Vale Buderim tram' 1935). The local community was in uproar at the remaining debt. During my research, I was hoping to find romantic pieces about people missing the presence of the tram, but I only found expressions of desperation and anger. The entire 9 miles (14.5 kilometres) $)^{2}$ of track was sold for $£ 700(\$ 430,300)$ and the Krauss locomotive for $£ 150(\$ 92,210)$ - described as 'a drop in the ocean' ('Sold Buderim tram rails for $£ 700$ pounds' 1936) considering the debt: 'With the rails removed [the tramway] moves on to the days when the cuttings and bridges will be the severe reminders of the "little iron horse"' ('Vale Buderim tram' 1935).

The state government had been banker for the tramway, taking on very little of the risk, and perhaps for a time, the post-tram aftermath was the unmaking of Buderim. Meanwhile, the forest regrew, reclaiming much of the mountainous parts of the track, with the sleepers rotting away or becoming buried. Much tramway land was resumed back into the farms from where it was donated. With time, urbanisation and influxes of new residents into the area meant the tramway was largely forgotten.

\section{The emerging walking track assemblage}

Today the Buderim-Palmwoods Heritage Tramway site comprises a gently graded, well cared-for walking track extending 2000 metres (1600 metres is heritage listed) in bushy surrounds of regrowth forest. The track is a segment of the original 11.5 kilometre tramway line that was completed in 1913, running down Buderim Mountain via Mons through Forest Glen to Palmwoods, where it connected with the main railway line to Brisbane. The walking track is entered from Telko Road, off Mons Road, midway between Buderim and Forest Glen. Although much of the track parallels busy Mons Road, noise is minimal. The heritage connections to the tramway are well explained through signage, and the ramped zig-zag access to the walk at Telko Road ensures accessibility. The walking track is listed on the Queensland Heritage Register and is also included in The Illustrated Burra Charter (Marquis-Kyle and Walker 2004: 52) as an example of conservation initiated by the community. The story of the Buderim-Palmwoods Heritage tramway site is multilayered, and moves across different times and different sets of actors. The story cycles through emergence, decline and re-emergence. A strong community effort underlies the story: the tramway was born in the community and still abides there.

This heritage tramway is a rare gem, and in many ways charmed. The Sunshine Coast Council is generally very supportive of heritage places and activities: its heritage levy on ratepayers ensures a level of funding enviable of most local government areas in Australia. The community group that has literally placed the tramway back on the map is the Buderim-Palmwoods Heritage Tramway Incorporated (BPHTI), formed as an offshoot of the Buderim Historical Society in 2003 (Fraser and McGarvie 2014: 4). The members of the BPHTI are highly motivated, with a rich range of highly developed skills and the ability to attract resources. The Buderim community itself, while constantly growing, conveys a sense of being close knit, taking pride in its heritage. These factors together create ideal conditions for heritage to flourish. Less ideal are the constant development pressures and the growing population, where even small impingements can collectively erode heritage value. There are no guarantees of survival with any heritage listing, and a multitude of forces act upon any heritage assemblage, making it difficult to protect. 


\section{The assemblage approach}

This article uses the concept of assemblages, as conceptualised by Gilles Deleuze and Félix Guattari (1987), to explore the value created by the walking track from the tramway heritage and the ongoing management challenges in its use, conservation and development pressures. The core of any assemblage is the need to solve a problem or produce something, acting to draw the assemblage elements together: '[An assemblage] is a new relation between content and expression that was not yet present' (Deleuze and Guattari 1987: 586). The problem being addressed by the tramway assemblage was creating a way to share and conserve the tramway heritage: the solution was making the walking track. The emergence of the Buderim-Palmwoods walking track assemblage comprises the interactions of components, the interplay of forces, the processes and territorialisation. Changes created by these processes are both tangible - for example, the creation of a walking track - and intangible - for example, the creation of a place thick with emotional connections. Assemblages are composed of 'elements that may be human and non-human, organic and inorganic, technical and natural' (Anderson and McFarland 2011: 124) and, as mentioned, tangible and intangible - there are many ways to divide an 'assemblage pie'. Assemblages draw attention to both the components and, importantly, the interplay of creative and disruptive forces, helping to explore the creation of value, and at times its destruction; heritage is viewed as a process rather than a fixed entity.

As with any heritage assemblage, the whole is more than its parts, and has capacities beyond the sum of its components. The terms that Deleuze and Parnet (2002: 69) use for the interrelationships are liaisons, co-functioning, symbiosis, sympathy, alliances, contagions, epidemics and the wind. The tramway's emergence story below reveals a range of assemblage components as well as external forces acting upon it. Components include an archaeological student (Neil); a map maker (Trevor); Trevor's map of the route; Ron's family and other neighbouring families; tramway remnants (cuttings, embankments, culverts and drains, drill holes and a cattle grid); the Buderim Historical society; the BPHTI; the track neighbours; a Conservation Management Plan project; a lush sub-tropical environment; council; the state Environmental Protection Agency (EPA); and non-material components, including fortitude, strong motivation, Quaker stories and serendipity. The external forces evident in the story are the natural environment; local property development; community support (and inertia); and both local and state government bureaucracy.

Assemblages form from the underlying social, organic, material and non-material environmental strata (Deleuze and Guattari 1987: 586) and are in a state of flux. The components form a 'flat' rhizomic interconnected structure rather than an ordered, hierarchical, structure. Symbiosis is present in the connections: Deleuze and Guattari (1987: 383) use the example of a wasp and an orchid. Connections can be of a material nature: both orchid and wasp have physically adapted to depend on each other, and there are emotional ties of need, and expressive ties - the beauty of the flower attracting the wasp. The components have autonomy (DeLanda 2006: 18): the wasp approaches the flower of its own accord. Assemblage components can change, be removed or remove themselves, but it is considered the same assemblage although obviously changed - highlighting that these are active processes, 'a becoming that brings the elements together' (Wise 2011: 91). Like a Heroclitean 
river, assemblages respond and change, affecting the flow: you never really meet the same one twice.

Assemblage is both a tool of analysis and of synthesis (DeLanda 2006: 14). Macdonald (2009: 119) suggests that 'an assemblage perspective potentially provides more nuanced accounts of complexes of relationships'. A piece of heritage such as the tramway can undergo many processes: discovery, re-emergence, adaptive re-use. Assemblage helps in considering the component parts and how these work as a coherent whole, as well as the flows within. A number of assemblages could be considered in the life of the tramway track, including a map-making assemblage (the initial mapping of the track) or a restoration assemblage (the restoration of the Krauss locomotive that serviced the track). This article focuses on the walking track assemblage itself, its emergence encompassing the reinstatement of a section of the track as a walking track, including the clearing, creating, conserving, maintaining and heritage listing of the track.

\section{The 'how and why' of this assemblage}

The atmosphere of the track is a real drawcard for locals. It permeates the senses the rainforest smells, bird calls and wing flutters, scuttling water dragons, the luscious lime-greens of the sun filtering through the leaves and fronds, and the peace. Anderson (2009: 78) writes of atmospheres as the 'shared ground' from which feelings and emotions emerge - as transpersonal in this case shared by those enjoying the track. There is also a strong sense of being in a heritage place: the signage, the rough-hewn railway cuttings, the stone culverts and occasional weathered sleeper embedded in the track. There are also the stories that seduce, stories of a community, one hundred years ago driven to build the tramway, and now of the community, driven to secure this piece of heritage. I first came in contact with the BPHTI through developing primary school programs to engage students in exploring the tramway track, thereby connecting with the history, geography and civics curricula. It was a rich and impressive subject, drawing on an array of elements, traversing a varied territory with a number of conservation challenges. The tramway offered an ideal case study for exploring the interplay of elements inside and outside the assemblage, as well as the concept of territorialisation.

In approaching the research, I have adopted a mixed methods approach including ethnographic interviews, observations and surveys. The in-depth semistructured ethnographic interviews on which this article draws were conducted with four BPHTI volunteers and two community members with strong connections to the tramway (see Appendix 1). The tramway committee and key members were invited to participate. Two responded: Neil, who was the main protagonist in the emergence of the walking track; and Bruce, the treasurer. They recommended others, including Trevor, who initially mapped the track, and Doug, currently managing the Krauss locomotive restoration. They all gave permission to be named.

Surveys of users were conducted at the walking track. Twenty-seven groups of one to five walkers on the track were surveyed, representing seventy track users. Others observed using the track were counted. The data suggests the track is well used, although it is difficult to extrapolate a weekly number: one track user mentioned 200, and my numbers suggest at least that, and possibly over 250, depending on the weather. Of the groups observed, the twenty to fifty-five years age 
group made up over half (61 percent) of the users of the track. Numbers were fairly even between male and female users, and just over half the groups brought their $\operatorname{dog}(\mathrm{s})$. Most users (70 percent) came from Buderim, and the rest from nearby Sunshine Coast suburbs, except for one user from Brisbane, who worked in Buderim. The track is currently a place for locals, not tourists. Most found out about the walk because they lived nearby or drove past (56 per cent), by word of mouth (18 per cent) or online ( 20 per cent), while only 7 per cent came to the track because of print media. Of the groups surveyed, 40 per cent used the track more than once a week.

One survey participant told me about a ninety-three-year-old family friend, Ron Hooper. I subsequently met with Ron and his sister, Evelyn Bell, whose husband Fred volunteered with the BPHTI, making metal parts for the restoration of the Krauss. I walked the 4 kilometre return track with Ron, listening while he pointed out features of the tramway and reminisced about life on the property. Other opportunities added to the formal interviews: taking Ron and Evelyn to visit the restored Krauss engine, which they had never seen, and Neil and Bruce giving me a tour of Buderim village and showing me the path of the tramway and remnant infrastructure. I took photos on these occasions, kept notes and wrote reflections. The mixed methods approach helped to focus on community needs and heritage value created by the track while allowing for some serendipitous meetings.

\section{The becoming of the walking track assemblage}

Fifty years after the tramway had ceased operation, Trevor Robinson, a plant operator and long-time resident of Palmwoods, became interested in its history. During the 1980s, he had begun collecting stories of Palmwoods' local history, which 'was all little bits of pieces all the time, like a mixed jigsaw puzzle' (Trevor Robinson interview 2017). He tried to source maps but there were none, so he started going for walks. Trevor recalls that, 'I was just taken in by it' (Trevor Robinson interview 2017). He knew it had to be mapped before both memories and any chance to locate the tramway traces faded. With no knowledge of mapping, Trevor decided to 'have a crack at it'. He started making rudimentary maps, collecting photos and documents about the tramway, and garnered some support from council's mapping and planning section, which provided maps and a person to record his findings. When Trevor stood atop of what could only be a deep cutting in the bush off Mons Road, he knew he had found its route to Buderim. The tramway map slowly emerged. From that work, a map (see Figure 1), visualised by Trevor in 1998, today stands at the picnic area near the start of the track. The sign is a physical expression of his ideas, but actualisation of a track would take years, and the help of council and others in the community.

In 1994, Neil McGarvie entered the tramway story. In his retirement he was studying a Graduate Diploma of Humanities (Archaeology) with the University of New England and was looking for a subject for his Conservation Management Plan (CMP) assignment. Merle Walker of the Buderim Historical Society suggested the tramway. It did not take long for Neil to track down Trevor, the map-maker. For Neil, his first view of the overgrown track, standing before a wall of lantana that concealed any number of challenges, must have been daunting. Having spent his 


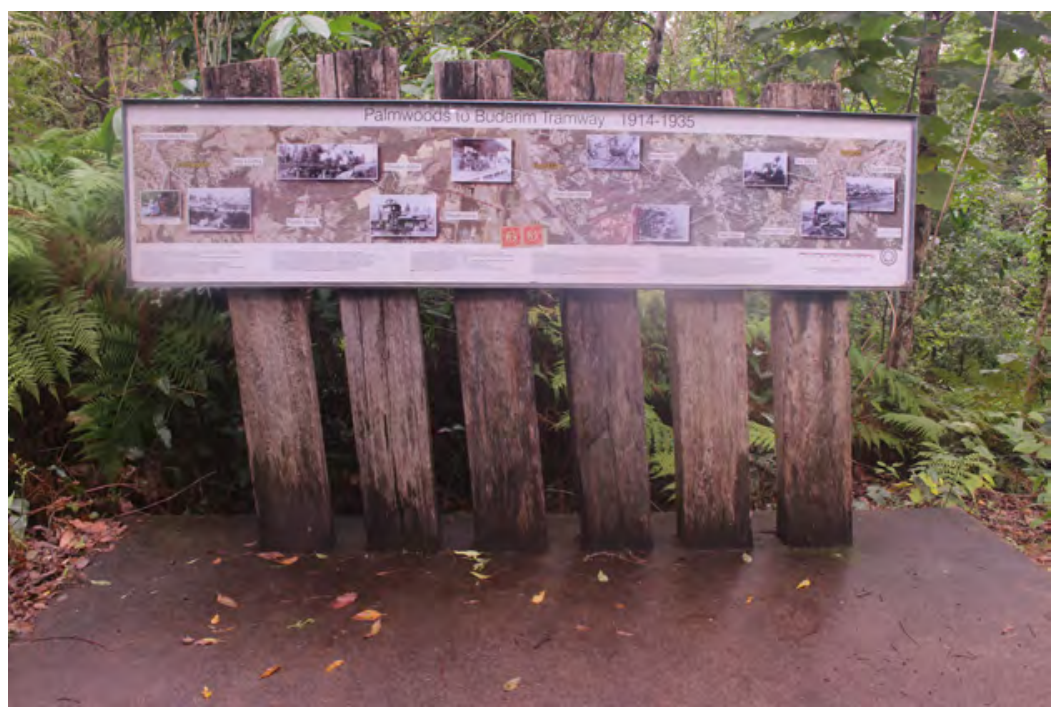

Figure 1

(Colour online) Trevor Robinson, who mapped the tramway route end-to-end, envisaged this map with the track overlaid on aerial imagery of the terrain. This map is mounted on sleeper posts near the commencement of the walking track. (Source: Janis Hanley).

early years as a farmer, Neil had a fair idea about the hard labour it would take to find and stabilise some semblance of a track. Neil embarked on his CMP assignment. CMPs, however, do not usually involve large-scale recovery of the heritage; this was a huge undertaking. Fortunately, Neil's motivation went beyond the task at hand: 'What a mess this was ... there were twenty-two culverts and they'd never been serviced or opened; everything was blocked and washed out. I was afraid the community would lose this heritage memory - it was going to go unless we did something. That was the motivation ... to do something to keep it' (Neil McGarvie interview 2017).

In the initial stages of this track assemblage, there were only two human players and 1600 metres of weeds, blocked culverts, cuttings and deteriorating track; however, Trevor and Neil were inspired by the idea of what could be restored. Once the undergrowth was cleared, the next job was getting the drainage working to stabilise the track and stop washouts. This meant locating and clearing twentytwo culverts. Neil devised an ingenious method of finding the culvert headstock, the area where the waters gather around the drain opening (see Figure 2). $\mathrm{He}$ commented that 'the culvert pipes were laid in the gully before the embankment (which might be 30 metres high) was built on top of it. You could go down to the bottom and find where the outflow pipe was: it was usually still open; it might have a few rocks in it and that sort of thing' (Neil McGarvie interview, 7 May 2017). Neil would climb down to the bottom of the gully, mostly on his own:

It was a steep climb; you had to have ropes on trees, and I had a little compass. I took a compass bearing, up the inside of the pipe, assuming they were all were straight, and I'd tag a tree near the outflow section. Then I'd go back up onto the embankment and take a reciprocal bearing on that tag mark and you could extend 


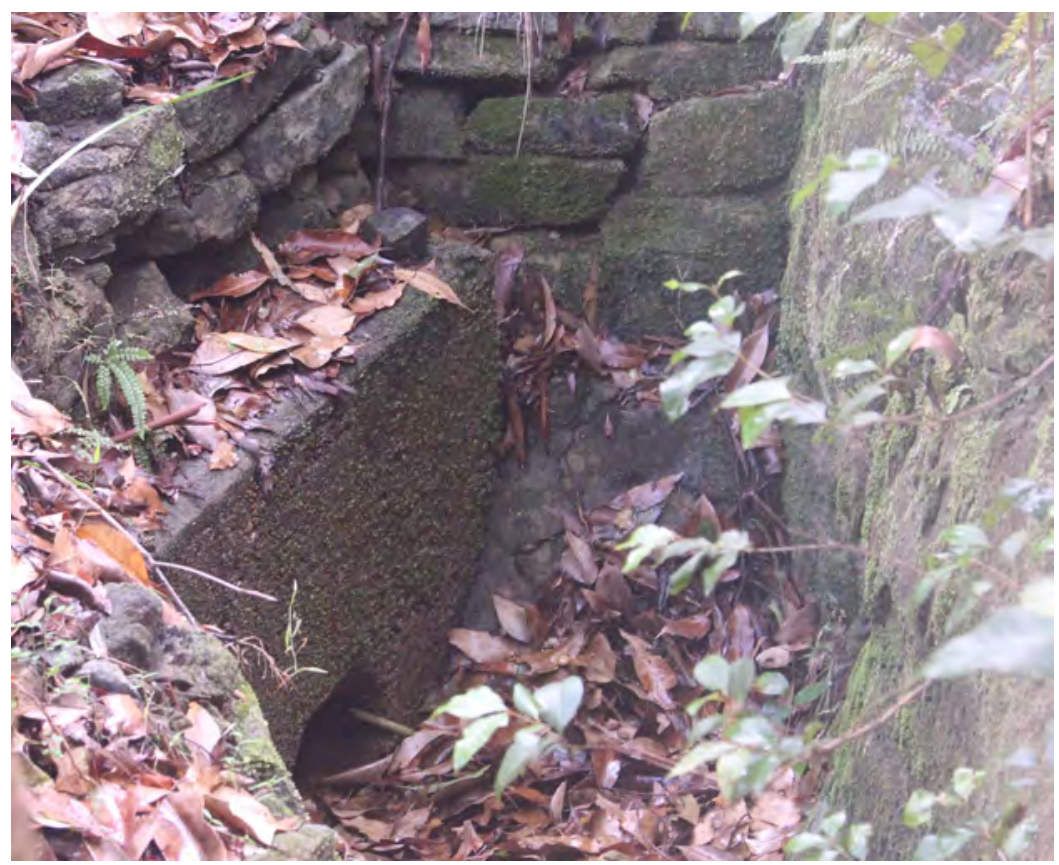

Figure 2

(Colour online) Culvert headstock on the tramway track - gathers the waters to flow into the drain running under the track embankment and down to a stream at the bottom of the gully. (Source: Janis Hanley).

it down the other side to where the blocked head stone was ... Some were buried three metres deep: there was a lot of digging — all picks and shovels and crowbars (Neil McGarvie interview 2017)

Serendipity played a role in the track emergence. A Council surveyor on the track, who was also a water diviner, saw Neil's trouble locating a drain, and offered his skills. After some rain, and using his divining skills, he located it- the only curved pipe of twenty-two culverts. Later, a Telstra worker on an adjoining property saw Neil struggling to find another culvert. He offered help using his small excavator, working all day, digging down about nine feet. He never found the head but must have unblocked it; the culvert has worked since. Neil remembered, 'We said to him at the end of the day, "This machine costs money to run, there's all the fuel, and there's your time, what are we going to do about that?" The response? "What do they pay you two fellas?"' (Neil McGarvie interview, 7 May 2017).

Fortitude was key to a successful outcome. This 'washout' story encapsulates their effort and relentless will. After removing lantana from a track section, Neil and Trevor discovered a portion of the embankment had washed out, leaving a hole over a metre wide and nearly 3 metres deep. The hole ruined the track's integrity and its potential to become a walking track, so Neil and Trevor decided that each time they walked down the track, they would take a rock with them and place it in the hole. It took them just on two years, but they filled that hole. Fortitude also is evident here through its connection to Buderim's past. Neil has a theory about the 
nature of the Buderim community that created the tramway in 1913. 'That's been the most interesting part of it all to me, to find out why these people did this,' he said (Neil McGarvie interview 2017). I asked him what drove this community of fruit-growers to take on a tramway construction - approach state Treasury to apply for a grant, engage an engineer, shape the project and take on the risk of paying off the loan. He said:

They were a different group of people ... a lot of Quakers and people who were referred to as Fortitude men. The Presbyterian Church chartered ships and brought them out from the United Kingdom. The first ship that came was called The Fortitude. Where they camped on arrival to Brisbane was later named Fortitude Valley ... They'd been brought up reasonable strictly in these different faiths. They had a tremendous work ethic and a tremendous community alignment. They weren't just individuals trying to fill their own pockets. ... people who were here knew how to influence government and they had political sway. (Neil McGarvie interview 2017)

To Neil, the lesson in this is to understand and 'know what people are like: listen to the community' (Neil McGarvie interview 2017). Neil's CMP assignment received a High Distinction. The Buderim Historical Society put the track segment forward for Queensland Heritage consideration. It was registered, and the significance statement closely mapped Neil's CMP. According to the Queensland Heritage Register (Queensland Government 2016), its significance to Queensland history is as a specific response by settlers to 'economic and social pressure'. The tramway is rare because of its 'two feet, six inches [75 centimetres] gauge, and its 'private' (local government) construction' (Queensland Government 2016). It has aesthetic significance through its 'considerable visual appeal, particularly the steeper hilly section ... complemented by the ... grandeur of the construction modifications to the landscape (i.e. the railway cuttings), especially as they were achieved in a horsepowered era' (Queensland Government 2016). Further, 'It has a special social and cultural association to the local communities serviced by the tramway' (Queensland Government 2016). Heritage listing gives the track assemblage agency — it becomes an entity with rights. These rights, however, are contingent upon the degree of support provided through legislative instruments, processes and advocacy. Community has a key role in conservation as the eyes and ears of the place, being vigilant to potential harm.

This walking track assemblage had grown to include, among other things, a CMP, a state heritage listing, additional members of the community, an infectious drive to reinstate the track and increasing awareness of residents bordering the track. Each element joining the assemblage has changed its capacity. A state heritage listing can certainly exert its own power, affecting what people do. It can change people's attitudes, provide visibility, bring the heritage code into effect and influence building work on neighbouring lots. A listing also raises the expectations of those who wish to see a place conserved and can bring disappointments, but these generate other actions. The listing has agency to change behaviours, just as inanimate objects such as a blocked culvert can draw a response. The interrelationships between things, and people and their emotions affect the assemblage and its relations with the rest of the world. Over time, the assemblage kept changing, drawing both enablers and resistance, slowly emerging to become a walking track. The BPHTI and the local council 
organised funding and works on a complex, a ramp for disabled access, picnic tables, seats, interpretive signage, two books, maps, botanical research, brochures, a website, a Facebook page and guided walks for schools. Bruce Horton, treasurer and grant writer, said, 'We always only had a small group of people. I don't think we've had more than nine or ten ... If ever we go to the community for something, they're cooperative' with funds and work-in-kind (Bruce Horton interview 2017). The people of the local community were powerful enablers.

Neil is now in his mid-eighties. It is over twenty years since he started work on the track, but the fortitude persists. He has continued carrying out minor maintenance tasks, checking the culverts, collecting sticks after storms, keeping an eye on weeds, tending a colony of rare giant moss, oiling the seats and alerting council to larger maintenance issues, although recently council has taken over these tasks. The track users and people on nearby properties independently contribute. I observed one young woman carrying a whole bag of sticks. I asked her whether she was collecting kindling. She said no, she was clearing the track of sticks for her and her mother who run there almost daily, and for other runners too. Many I met on the track spoke of seeing Neil working on the track.

\section{Understanding the walking track territory}

'The first concrete rule of assemblages is to discover what territoriality they envelop' (Deleuze and Guattari 1987: 503), and consequently the ways the boundaries are defined. The walking track is solid in parts, such as the sandstone cuttings of the track; more permeable elsewhere, such as the trees lining the track edge; or expressive, as in a codification in the form of maps, or the heritage listing. Deleuze and Guattari (1987: 591) express the territorial making and unmaking processes as 'territorialisation' and 'deterritorialisation'. DeLanda (2006: 12) often uses the word 'stabilise' for 'territorialise': 'One and the same assemblage can have components working to stabilise its identity as well as components forcing it to change, or even transforming it into a different assemblage'. Some components may act as both, like the sandstone cuttings offering clear solid boundaries while the water they channel can erode and destabilise. Deleuze and Guattari (1987: 383) write of the degrees of territorialisation through to deterritorialisation as a continuum. The sharper the territory, the more fixed. Moving down the continuum to deterritorialising highlights permeability, change, openness and responsiveness of boundaries. The assemblage concept also creates a new relationship between the materiality of the assemblage and the expression, which is another continuum. Items, 'things' in the assemblage, take on roles that range from material to expression (or coded representation), which can be read and expressed in different ways - examples are a map or heritage listing. Expressions can also be sounds: bird songs, smells of rainforest leaf matter or resident fauna scenting their territory. Expressions draw a behavioural response from others. A scent could draw a response of fear from an animal and avoidance behaviour, whereas a sense of serenity on the track may encourage people to linger to enjoy the surrounds.

This section looked at the variables at play in the walking track assemblage: territorialisation, deterritorialisation, material and expression. There is also the temporal aspect, however. Marcus and Saka (2016: 103) suggest that assemblages have 'no specific or distinctive life-span'. An assemblage may differ from season to 


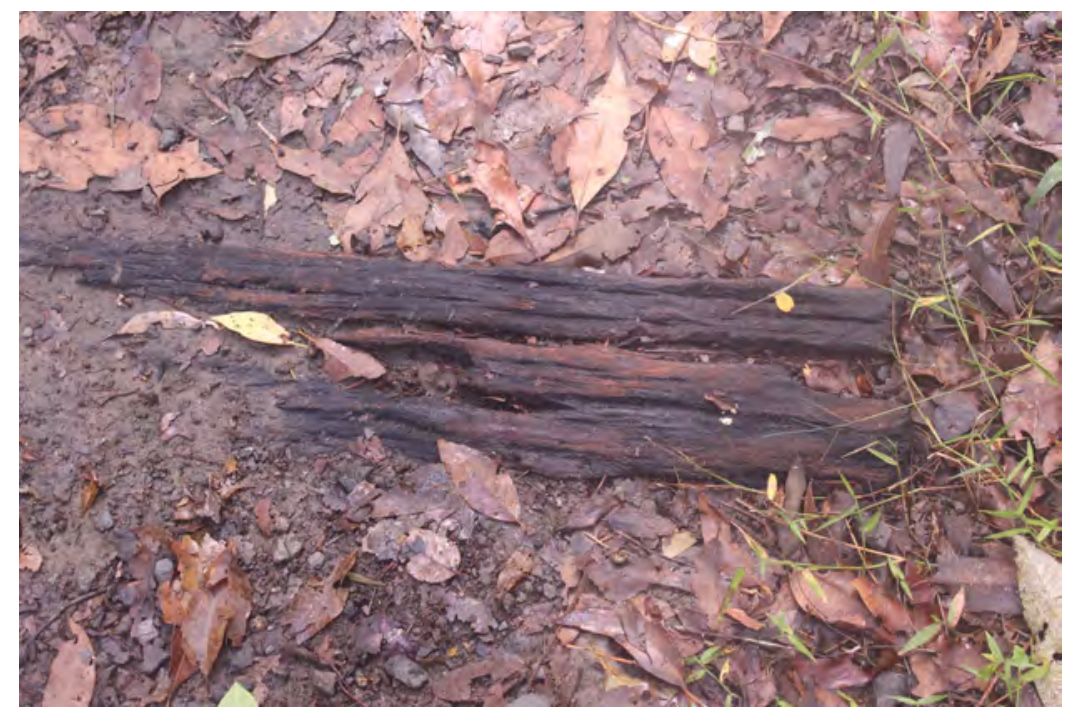

Figure 3

(Colour online) Sleepers embedded in the walking track, vulnerable to weather, and track usage. (Source: Janis Hanley).

season, from day to night, from moment to moment, and territories can change accordingly.

\section{Culverts and cuttings materially stabilising the track territory}

In places, deep stone cuttings provide a sharp physical edge to the track's territory. Still material but permeable in nature, culverts stabilise the track through collecting the water and letting it pass under the track. The natural environment is a constantly destabilising force acting on the material components: weeds, falling sticks, branches and sometimes trees; frequent heavy deluges wash leaves and debris into the culvert headstocks. Culverts are key to maintaining the physical track integrity. Physical maintenance measures ensure they remain functional, keeping water off the track; however, water slowly degrades the few remaining sleepers embedded in the track, further loosened by foot traffic (see Figure 3). Like the cuttings and culverts, the sleepers also have an expressive role. The sleepers are a surprise when walkers happen upon them, strongly reasserting the tramway's presence. Their decline and loss are noticeable. A CMP is an expressive component directing the processes for stabilising these and other material components; it is not clear whether the council has a formal CMP for the walking track or has allocated sufficient resources for ongoing conservation. Developing community support and sharing stories solidifies the track's place and identity in the community and helps to attract more enablers, volunteers and funds to actualise the physical track stabilisation. The physical territory, objects and fabric are the main focus of heritage management planning, and often social aspects are overlooked or insufficiently resourced. 
The drill marks in the solid sandstone cuttings are another expression. I have only noticed a handful of the marks, and they are unseen by most walkers until the finger-size channels in the rock are pointed out. Once you notice these rock-face scars, you can imagine holes being drilled into the rock, explosives inserted, men crouching behind boulders, a spark traversing the rocky terrain, then kaboom! The drill-hole markings are small, but they express the construction process and methods of a hundred years ago. In our walk along the track, I watched Ron Hooper stand up close to the rock -faces, silently shaking his head in awe. Ron reminded me about the hard labour involved in the construction: the holes were drilled by hand - no easy task then. Horses would have helped with hauling out the rubble, but every rock would have been loaded by hand and the earth loosened with picks, then shovelled and barrowed. A whole story is expressed by a drill mark in the stone.

There are also important components sitting outside the formalised territory expressed by the state heritage listing, and a material 'deterritorialisation' process occurring. The Telko walking track is the most intact section in the 11 kilometres of the route; however, while much of the old track has now been built over, significant features remain - a line of pines marking the track running through Buderim village, remnant embankments and cuttings, the Shay engine (the first to operate on the track) buried in an embankment and approximately 50 metres of dry stone wall close to Buderim village. Sadly, the hundred-year-old dry stone wall was on a private lot under development, and was demolished in August 2017. It would be beneficial to bring these parts of the assemblage within the state listing before more are lost.

\section{The permeable vegetation boundary}

Trees lining the track form a permeable boundary and an expressive element of the track. The natural environment is key to the track's aesthetic significance - the sounds of the wind through the trees; the shrill crack of whip birds; plant specimens, from delicate maiden-hair ferns to the dramatic ceiling of fan fern fronds; gangly gingers; and the feelings of peace when walking the track. Nearly all users surveyed on the track spoke of the peace in some sense, using words such as tranquillity, ambiance, serenity, sanctuary and healing. To them, the track was 'a little secret'; 'an escape to paradise', to 'something magical'. ${ }^{3}$ They valued the heritage but even more the sense of wellbeing. Nearly all users rated 'wellbeing' and 'natural environment' as extremely valuable aspects of the walk, compared with just over half finding its historical importance extremely valuable. Many mentioned a variety of natural, physical and emotional aspects, and some specifically mentioned the combination of heritage and environment. Two users spoke of visualising the tram as they walked. The aesthetic and 'cocoon-like' atmosphere strengthens the track assemblage. The trees surrounding the track fold into the vegetation on neighbouring properties, seamlessly giving rise to a sense of being enveloped by forest. Track users, however, mentioned various elements of ongoing development occurring on properties alongside: trees being felled, the noise of construction and, in a recent case, an imposing rock retaining wall erected right on the boundary of the track. Track-users were concerned about these encroachments harming the visual aesthetic and atmosphere, and the intrusions on walkers' enjoyment through the 
houses perched overlooking the track. These undefined visual boundaries need strengthening. Working to deepen the treed border could solve a number of issues. A planting scheme could occur along both the track edge and in neighbouring properties. These measures can be supported through encouraging land-owners to participate, perhaps in planting borders, providing information, suggesting species and providing plants and volunteers to assist. On a grander scale, during the course of this research, owners of a neighbouring lot generously donated to council a parcel of their land adjacent to the former Mons Road station site. It has been officially named the 'Mons Station Nature Reserve'. This is new territory for the track and may encourage others.

\section{Codes expressively stabilising the track territory}

Expressions stabilising the assemblage include heritage listings and maps of various types - historical or tramway routes. Planning and policy documents are included, as well as CMPs and interpretive signage. The 'Telko' track segment, adapted for reuse as a walking track, is clearly depicted on the heritage overlay map as state heritage. While often a state listing could be seen as a tool of protection, the increasing erosion of the track aesthetic raises questions around its effectiveness. Private certification of development work often overlooks heritage protections, and there is limited consideration for visual impact in regard to setting. The track runs along the side of a gully, and the steepness of the natural terrain means significant retaining may be required. Bordering lot sizes are large (several thousand square metres) and zoned as either Rural Residential or Limited Development. Built structures are highly visible, and when overlooking the track are imposing and damaging to the environmental and atmospheric fabric. The acceptable outcomes in the heritage overlay code is clear, but not necessarily achieved: 'The scale, location and design of the development is compatible with the heritage significance of the adjoining State heritage place ... including its context, setting and appearance '(Sunshine Coast Council 2017: 8).

Improved expression is part of the answer. The heritage overlay code, in terms of properties adjoining built heritage, mainly addresses concerns about front streetscapes and architectural style. The tramway track has a rear alignment to these sites, and the code offers little guidance on natural settings. This requirement could be made more explicit in the policy and in more informal ways describe the impacts of different types of works and offer alternative suggestions. Directly connecting with property owners can open up discussions around practical ways to support the aesthetic of the adjoining heritage track. Planning codes only operate when development is occurring and only work if invoked, so they cannot mediate activities outside of development; however, interest, being informed, guidance and connection can.

\section{The real track territory}

An important, sizeable issue around the assemblage territory is the possibility of creating a walking track from Buderim Village to Palmwoods, following the tramway route as much as possible: re-territorializing the tramway track, joining together the piecemeal remnants. The end-to-end walk was mentioned by BPHTI 
members and walkers I surveyed. The approach taken currently is to wait for new developments on sites to occur that enable connecting in new track segments and approaching the developers. This is a long-term strategy, requiring close monitoring to be effective. Trevor first mapped the route in the late 1980s. Even at that time, the track continuity was compromised in parts by land subsumed by property alignments. However, if the entire track route had been embedded in the town plan when the track was first heritage listed in 2000, the entire tramway may have been conserved as an asset. It is possible that the heritage track assemblage could be made a primary planning consideration for the area, particularly if the tramway route was not only on an overlay map, but a core consideration of planning and design. Examples of better integrating heritage into planning, by making heritage central to planning, can be seen in the work by Janssen et al. (2012: 18). By strategically making heritage the focus of planning, landscapes protection was enhanced, and local identities made stronger; 'preservation through development' was the project mantra, where 'heritage management is interwoven with urban and spatial planning' (Janssen et al. 2012: 18).

\section{The expressive community boundary of interconnection}

Community interconnection happens through activities, events and stories that let others into the assemblage, using their leisure time, skills and resources, and in turn often adding a layer of their own stories. Contemporary use of the track by locals for leisure activities (walking, running, dog walking and family activities) bolsters the awareness and increases the social significance of this heritage. The community use is a component cementing in the current layer of heritage significance. Creating and strengthening connections between the human components of the track assemblage can stabilise the assemblage, attracting offers of support and serendipitous encounters. Neil spoke of active 'campaigning' for new recruits and attending various meetings across the Sunshine Coast to garner interest. It seems, too, that excellent relationships have been developed with many people on neighbouring properties, as evidenced by the recent land donation for the Mons Station reserve. The BPHTI intuitively developed these relationships, and Neil mentioned his experience working with Aboriginal communities guiding the process. Drawing more community members into the assemblage enables better understanding of both the private and the public value of the track - and of competing values. Community connections can also occur through learning activities, and both Neil and Bruce mentioned the development of education kits as a key way forward for the track, thereby building associations with teachers, students and their families. Another possibility might be engaging artists. There could be sculptural works along the track, connecting to a whole new segment of the community. Focusing on connections and what they can add to an assemblage opens new rhizomic lines of creativity. Connection is at the heart of every assemblage: it is its lifeblood.

\section{Conclusion}

Considering the multitudinous elements forming an assemblage and its territories provides understanding of heritage as a process and a becoming, rather than a fixed entity. Assemblage enables a nuanced perspective of heritage. The emergence of the 
walking track assemblage has created a public heritage asset - a well-interpreted walking track, a place for exercise or quiet enjoyment, but one experiencing constant external pressures. It requires thoughtful management. Assemblages sound like an abstraction, but they are not. The components exist both materially and as different forms of expression - for example, the drill-holes in the sidings exist materially and express the method of construction. Contemplating territories, their stabilisation and expression are stimulating and productive prompts for considering ways of keeping heritage alive and enjoyed while managing its future. A heritage assemblage is akin to a living organism, highly responsive and with a potential for volatility. Long-term sustainability means adapting to constantly changing conditions of natural and human environments, and conservation means making decisions that discern between desirable and undesirable changes. It requires awareness: boundaries can protect, and at times erode, heritage values. The affective flows of emotional responses and intangibles, such as atmospheres, are also agents of change. Seeking stabilising components, enabling adaption to external forces and considering how individual components connect across boundaries is productive, particularly for the long-term sustainability. Identifying elements of both territorialisation (such as clear lines of heritage protection spatially) and deterritorialisation (the blended treed boundaries) as potentially stabilising forces moves the debate away from the adversarial approach often taken with heritage to the collaborative. Tensions will still arise, but a more symbiotic approach offers ways forward for those who do want to support heritage. This approach supports the articulation and ongoing practices honouring the relationships in the larger heritage picture.

Considering the ways heritage territory is expressed in policies and planning is key in positioning heritage for long term enjoyment of the richness and textures of heritage. Janssen and colleagues' (2012) approach of making heritage central to all planning activities and decisions, directly addressing heritage management planning issues from the start (rather than heritage as an afterthought), is a powerfully expressive way to mark and stabilise a territory: the heritage is embedded in the community fabric. In this case, just embedding the end-to-end path of the track in planning maps would encourage allowances to be made for the track in all manner of decisions about roadways, footpaths, community renewal and a variety of projects.

Assemblages help us look beyond the fabric (the materiality) of heritage to appreciate what has been created and the myriad responses: to properly discern the value of heritage, of all the components and their affects, enabling responsive management of places. As Moore (1995: 52) points out, 'Value is rooted in the desires and perceptions of individuals - not necessarily in physical transformations, and not in abstractions called society or community.' The assemblage approach draws us back to the actual - the material and expressive roles of components and the relations between them. Assemblages highlight the processes for creating heritage value and bring insights through recognising the elements affected both within and external to the heritage-assemblage. It extends conservation beyond the fabric, the architectural and aesthetic, to the atmospheric, the emotional, the interplay of natural forces, the connections and the action of the expressive. It turns the heritage components 'from nouns into verbs', recognising their action and agency, and their ability to affect and be affected. Many forces are at play with heritage, and assemblages offer ways to see into the interactions of a 
place more clearly and on many levels, aiding its management and peaceful enjoyment over time.

\section{Acknowledgements}

I wish to acknowledge the support of the Buderim-Palmwoods Heritage Tramway Inc. for their openness and enthusiasm, Ron Hooper and his sister Evelyn for their warm hospitality, and my PhD supervisors, Professor Sarah Baker and PostDoctoral Fellow Adele Pavlidis, for their sage guidance and advice.

\section{Notes}

1 I chose labour cost as the basis for valuing pounds from 1913, as it puts it in terms of farmers' earnings to repay. All values were converted from Australian pounds in 1913 to dollars in 2016.The economic cost relative as a percentage of GDP would be $\$ 137$ million). Relative values as per Hutchinson and Ploeckl (2018).

2 According to Fraser and McGarvie (2014), the original length was 11.5 kilometers ( 7 miles, 15 chain), not 9 miles as reported in the Nambour Chronicle, 16 August 1935, p. 9, although the 9 miles may have included rails from sidings.

3 The descriptors used for the tramway walking track were drawn from participants' responses to the survey that I conducted on the track.

\section{References}

Anderson, B. 2009. 'Affective atmospheres'. Emotion, Space and Society 2(2), 77-81. Anderson, B. and McFarland, C. 2011. 'Assemblage and geography'. Area 43(2), 124-7.

DeLanda, M. 2006. A New philosophy of society: Assemblage theory and social complexity. London: Continuum.

Deleuze, G. and Guattari, F. 1987. A thousand plateaus: Capitalism and schizophrenia. Minneapolis, MN: University of Minnesota Press.

Deleuze, G. and Parnet, C. 2002. Dialogues II. New York: Columbia University Press.

Fraser, G. and McGarvie, N. 2010. The Buderim-Palmwoods Tramway. Buderim: Buderim-Palmwoods Heritage Tramway Inc.

Fraser, G. and McGarvie, N. 2014. A short history of the Buderim-Palmwoods Tramway. Buderim: Buderim-Palmwoods Tramway Inc.

Hutchinson, D. and Ploeckl, F. 2018. 'Five ways to compute the relative value of Australian amounts, 1828 to the present'. MeasuringWorth, http://www. measuringworth.com/australiacompare, accessed 26 July 2018.

Janssen, J., Luiten, E., Renes, H. and Rouwendal, J. 2012. 'Heritage planning and spatial development in the Netherlands: Changing policies and perspectives'. International Journal of Heritage Studies 20(1), 1-21.

Macdonald, S. 2009. 'Reassembling Nuremberg, reassembling heritage'. Journal of Cultural Economy 2(1-2), 117-34.

Marcus, G.E. and Saka, E. 2016. 'Assemblage'. Theory, Culture \& Society 23(2-3), 101-6.

Marquis-Kyle, P. and Walker, M. 2004. The illustrated Burra Charter: Good practice for heritage places. Sydney: ICOMOS Inc. 
Moore, M.H. 1995. Creating public value: Strategic management in government. Cambridge, MA: Harvard University Press.

Queensland Government. 2016. 'Palmwoods to Buderim Tramway track foundation and formwork remnants'. Environment, Land and Water: Queensland Heritage Register, 20 January. https://environment.ehp.qld.gov.au/heritage-register/detail/? id=601711, accessed 26 July 2017.

'Sold Buderim tram rails for $£ 700$ pounds'. 1936. Nambour Chronicle and North Coast Advertiser, 21 February, 14.

Sunshine Coast Council 2017. 'Part 8 Section 8_2_9'. In Sunshine Coast Planning Scheme 2014. Sunshine Coast: Sunshine Coast Council, pp. 1-47.

'Vale Buderim tram! Little “iron horse's” final trip'. 1935. Nambour Chronicle and North Coast Advertiser, 16 August, 9.

Wise, J.M. 2011. 'Assemblage'. In C.J. Stivale (ed.), Gilles Deleuze key concepts. Durham, NC: Acumen, pp. 91-102.

\section{Appendix 1: Interviews conducted}

\begin{tabular}{|c|c|c|c|}
\hline $\begin{array}{l}\text { Name/interview } \\
\text { date }\end{array}$ & Employment & $\begin{array}{l}\mathrm{BPHTI} \\
\text { involvement }\end{array}$ & $\begin{array}{l}\text { Tramway } \\
\text { connection }\end{array}$ \\
\hline $\begin{array}{l}\text { Neil McGarvie } \\
\text { 7.5.2017 }\end{array}$ & $\begin{array}{l}\text { Retired senior public } \\
\text { servant, Education } \\
\text { Queensland, Graduate } \\
\text { Diploma of Humanities } \\
\text { (Archaeology) }\end{array}$ & Life member & Track-maker \\
\hline $\begin{array}{l}\text { Bruce Horton } \\
\text { 7.5.2017 }\end{array}$ & $\begin{array}{l}\text { Retired university } \\
\text { lecturer in education }\end{array}$ & Treasurer & $\begin{array}{l}\text { Gathering } \\
\text { funds }\end{array}$ \\
\hline $\begin{array}{l}\text { Trevor Robinson } \\
\text { 24.5.2017 }\end{array}$ & $\begin{array}{l}\text { Retired plant operator, } \\
\text { Maroochy Water }\end{array}$ & Life member & Map-maker \\
\hline $\begin{array}{l}\text { Doug Benckendorff } \\
\text { 24.5.2017 }\end{array}$ & Retired mechanic & Life member & $\begin{array}{l}\text { Krauss restorer, } \\
\text { now managing } \\
\text { final restoration } \\
\text { for display }\end{array}$ \\
\hline $\begin{array}{c}\text { Ron Hooper } \\
\text { 18.7.2017 }\end{array}$ & $\begin{array}{l}\text { Retired farmer and } \\
\text { retail manager }\end{array}$ & Non-member & $\begin{array}{l}\text { Neighbouring } \\
\text { farmer with } \\
\text { memories of } \\
\text { tram operating }\end{array}$ \\
\hline $\begin{array}{l}\text { Evelyn Bell } \\
\text { (nee Hooper) } \\
\text { 18.7.2017 }\end{array}$ & $\begin{array}{l}\text { Retired stainless steel } \\
\text { business partner with } \\
\text { her husband, Fred. }\end{array}$ & Non-member & $\begin{array}{l}\text { Evelyn's husband, } \\
\text { the late Fred } \\
\text { Bell, made parts } \\
\text { for the tram } \\
\text { restoration }\end{array}$ \\
\hline
\end{tabular}

